\title{
PROGRAM SOSIAL BUDAYA PENGEMBANGAN OBJEK WISATA MUSEUM TJOK AGUNG TRESNA DI DESA AYUNAN KECAMATAN ABIANSEMAL KABUPATEN BADUNG
}

\author{
L.G.M. Karisma ${ }^{1}$, A.N Marhaeni ${ }^{2}$, I.P. Kuswara A P ${ }^{3}$, Y. Lapian ${ }^{4}$, A. Andriani ${ }^{5}$, \\ I.G.N.S. Bramantha $\mathrm{P}^{6}$, L. Jasa ${ }^{7}$
}

\begin{abstract}
ABSTRAK
Desa Ayunan merupakan Desa yang terletak di Kecamatan Abiansemal, Kabupaten Badung. Memiliki alam yang indah, suasana pedesaan yang masih asri dan sejuk, dan lahan pertanian yang masih bertahan sampai saat ini ditengah pembangunan kota yang terjadi. Keberadaan Keadaan Desa yang seperti ini tidak terlepas dari banyaknya sejarah yang dimiliki Desa Ayunan. Dari keadaan seperti ini, maka mendorong Desa untuk membangun sebuah Museum di kawasan Desa yang diberi nama Museum Tjok Agung Tresna. Museum Tjok Agung Tresna berdiri atas gagasan seorang seniman yang sadar akan sejarah dan potensi yang dimiliki Desa.
\end{abstract}

Kata kunci : Seni, Budaya, Museum, Sejarah, Pengabdian Kepada Masyarakat, Desa Ayunan.

\begin{abstract}
Ayunan village is a village located at Abiansemal District, Badung Regency. It has a beautiful nature, cool and great village atmosphere, and farmland that still survive to this day amid urban development occurs. The existence of this village inseparable from the great history of Ayunan Village. From these circumstances, it is encouraging the village to build a museum in the village named Tjok Agung Tresna Museum. Tjok Agung Tresna Museum stands on the idea of an artist who is aware of the history and potential of the village.
\end{abstract}

Keywords: art, culture, museum, history, community service, Ayunan Village.

\section{PENDAHULUAN}

KKN-PPM merupakan kegiatan wajib yang dilaksanakan mahasiswa Universitas Udayana sebagai wujud pengabdian kepada masyarakat. Salah satu kegiatan inti dari kuliah kerja nyata KKN-PPM Universitas Udayana Periode XIII adalah kegiatan Inventarisasi dan publikasi Museum yang ada di Desa Ayunan. Museum Tjok Agung Tresna adalah museum seni lukisan yang satu-satunya ada di

\footnotetext{
${ }^{1}$ Mahasiswa PSi Ilmu Hukum, FH UNUD, Denpasar, megakarisma8@gmail.com

${ }^{2}$ Mahasiswa PS Ilmu Komunikasi, FISIP UNUD, Denpasar

${ }^{3}$ Mahasiswa PS Ilmu Komputer, FMIPA UNUD, Denpasar

${ }^{4}$ Mahasiswa PS Management, FEB UNUD, Denpasar

${ }^{5}$ Mahasiswa PS Sastra Inggris, FIB UNUD, Denpasar

${ }^{6}$ Mahasiswa PS Management, FEB UNUD, Denpasar

${ }^{7}$ Dosen PS Teknik Elektro, FT UNUD, Denpasar
} 
Desa Ayunan tepatnya berlokasi di Banjar Badung, Desa Ayunan, Kecamatan Abiansemal, Kabupaten Badung, Bali. Museum ini berdiri pada tahun 1984 dengan luas tanah 14 are dan merupakan museum milik pribadi yang bersifat "mini gallery". Sejarah berdirinya museum ini dikarenakan sang pemilik, I Ketut Murah, S.Sn, memiliki keinginan yang besar untuk dapat melestarikan tradisi dan kebudayaan Bali serta memperdalam pengetahuan generasi muda akan budaya yang diwarisi oleh nenek moyang.

Pada awalnya, koleksi museum yang dimiliki adalah berupa alat-alat pertanian tradisional daerah Bali, seperti bubu, lampit, tengala, ketam (ani-ani), gerejag, alu, lesung, nyiu, keroncongan sampi, dan lain-lain, yang mungkin saat ini tidak bisa ditemui lagi selain di museum. Seiring berjalannya waktu, koleksi yang dimiliki oleh museum semakin bertambah, mulai dari lukisan, patung, dan ukiran. Setiap karya seni memiliki keanekaragaman karya, diantaranya secara realis, naif, dan abstrak. Karya realis merupakan karya seni yang bersifat keindahan dan menarik. Kemudian Naif merupakan karya seni yang bersifat mistis, angker, atau seram. Sedangkan abstrak adalah karya seni yang menggambarkan sebuah wujud yang tidak natural dan realistis.

Museum Tjok Agung Tresna ini didalamnya terdapat karya seni lukisan dan patung, dimana untuk lukisan jumlahnya mencapai kurang lebih 500 buah dan untuk patung jumlahnya mencapai kurang lebih 200 buah. Harga lukisan yang terdapat di museum berkisar mulai dari puluhan ribu sampai puluhan juta. Lukisan ini berasal dari bermacam-macam daerah mulai dari dalam negeri sampai luar negeri.

Museum Tjok Agung Tresna ini mempunyai ciri dan sangat menarik karena adanya bangunan sangkep setinggi 17 meter. Menurut bapak I Ketut Murah, S.Sn, (Pendiri dan Pemilik Museum Tjok Agung Tresna), museum ini didirikan untuk melestarikan budaya dan menyalurkan hobi beliau karena kegemarannya tentang seni. Museum ini sangat berpotensi untuk dijadikan objek wisata. Namun, kurangnya dana pembangunan untuk memadai fasilitas karena bersifat pribadi sehingga tidak adanya campur tangan pemerintad daerah setempat. Akan tetapi museum ini telah di resmikan oleh Gubernur Bali pada 07 Juli 2008.

Meskipun demikian, hal tesebut tidak mempunyai dampak significant karena museum ini masih belum di promosikan dan di kenal kalangan masyarakat. Oleh karena itu hanya sedikit masyarakat yang tau tentang keberadaan museum ini, bahkan masyarakat di desa itu sendiri. Dengan kondisi ini program inventarisasi dan publikasi museum di buat. Program ini bertujuan untuk lebih memperkenalkan adanya aset wisata yang ada di Desa Ayunan ini. 


\section{METODE PEMECAHAN MASALAH}

Ekonomi keluarga merupakan salah satu indikator dari standar tingkat kesejahteraan keluarga masyarakat pedesaan. Pengukuran tingkat kesejahteraan bertujuan untuk melihat dan mengidentifikasi sumber penghasilan keluarga dalam memenuhi kebutuhan sehari-hari. Pada aspek ekonomi keluarga yakni pendapatan keluarga sebagai sumber pemasukan serta pengeluaran sebagai hasil atas penggunaan dana yang didapatkan oleh keluarga. Salah satu kegiatan berupa Publikasi dan Inventarisasi Museum Seni Tjok Agung Tresna. Adapun bertujuan untuk lebih mengenalkan Museum Seni yang terdapat di Desa Ayunan terhadap masyarakat lokal, nasional maupun di kancah internasional melalui publikasi serta dapat meningkatkan kualitas diri bagi para seniman yang ada di Desa Ayunan agar tetap berkreasi serta melestarikan segala tradisi di Desa Ayunan yang nantinya dapat menjadi potensi Desa Seni. Metode yang digunakan adalah pendekatan secara individu yaitu melakukan wawancara dengan pihak pemilik museum.

Berdasarkan atas permasalahan yang dihadapi, metode yang digunakan adalah penerapan model:

Metode pemecahan masalah yang digunakan adalah metode langsung, yaitu dengan melakukan wawancara tentang segala sesuatu yang berhubungan dengan museum Tjok Agung Tresna. Kemudian membuat akun media sosial melalui akun instragram, wordpress dan video tentang museum Tjok Agung Tresna agar lebih terkenal dikalangan masyarakat lokal, nasional bahkan dunia. Selanjutnya membuat plang (arah petunjuk jalan) menuju museum ini agar memudahan wisatawan yang ingin berkunjung. Hal ini diharapkan agar museum ini terutama desa Ayunan menjadi lebih dikenal dan maju pariwisatanya.

\section{HASIL DAN PEMBAHASAN}

Adapun tujuan dari kegiatan ini, yaitu untuk lebih mengenalkan Museum Seni yang terdapat di Desa Ayunan terhadap masyarakat lokal, nasional maupun di kancah internasional melalui publikasi serta dapat meningkatkan kualitas diri bagi para seniman yang ada di Desa Ayunan agar tetap berkreasi serta melestarikan segala tradisi di Desa Ayunan yang nantinya dapat menjadi potensi Desa Seni. Metode yang digunakan adalah pendekatan secara individu yaitu melakukan wawancara dengan pihak pemilik museum. Disamping itu, untuk meningkatkan daya tarik wisata mahasiswa KKN melakukan publikasi di media sosial melalui post-an foto dan video. 
Adapun kendala yang ada selama pelaksanaan program ini yaitu karena masih terdapat renovasi di beberapa bagian Museum sehingga kegiatan interview bersama pemilik museum sedikit terganggu. Hasil dari adanya progam Publikasi dan Inventarisasi Museum Tjok Agung Tresna yaitu mahasiswa mampu mengenalkan Museum Seni yang terdapat di Desa Ayunan terhadap masyarakat local, nasional maupun di kancah internasional melalui media sosial. Serta dapat meningkatkan kualitas diri bagi para seniman yang ada di Desa Ayunan agar tetap berkreasi seni serta melestarikan tradisi di Desa Ayunan yang dapat menjadi potensi Desa Seni
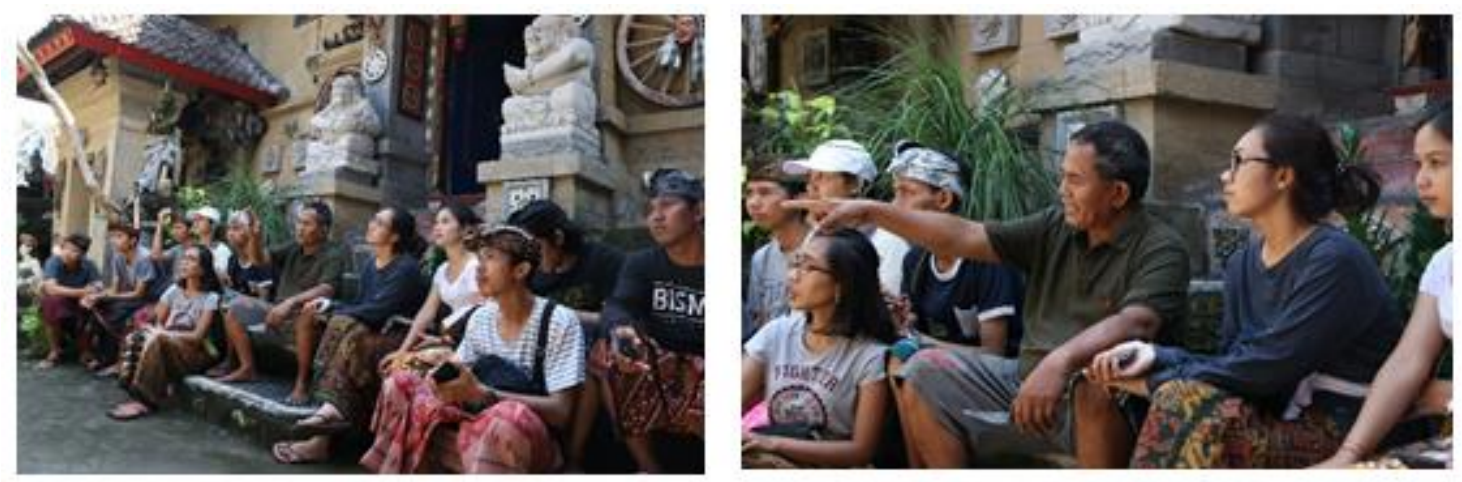

Gambar 1. Wawancara sekaligus inventarisasi dengan pemilik museum.

Hasil dari progam Publikasi dan Inventarisasi Museum Tjok Agung Tresna yaitu mahasiswa mampu mengenalkan Museum Seni yang terdapat di Desa Ayunan terhadap masyarakat local, nasional maupun di kancah internasional melalui media sosial. Serta dapat meningkatkan kualitas diri bagi para seniman yang ada di Desa Ayunan agar tetap berkreasi seni serta melestarikan tradisi di Desa Ayunan yang dapat menjadi potensi Desa Seni. Selain dari adanya hasil tersebut, mahasiswa KKN juga sudah membuat wordpress dan Instagram pribadi untuk Museum serta telah membuat video Youtube sebagai media promosi seperti :

- Link Wordpress: https://museumtjokagungtresna.wordpress.com

- Link Instagram: http://Instagram.com/tjokagungtresnamuseum

- Link youtube : https://youtu.be/mFymBgsNOAk

\section{SIMPULAN}


Program pengembangan potensi seni melalui publikasi dan inventarisasi Museum Tjok Agung Tresna berguna untuk meningkatkan kualitas diri bagi para seniman yang ada di Desa Ayunan agar tetap berkreasi serta melestarikan segala tradisi di Desa Ayunan yang nantinya dapat menjadi potensi Desa Seni. Selain itu, dengan adanya program pengembangan potensi seni melalui publikasi dan inventarisasi Museum Tjok Agung Tresna, mahasiswa KKN PPM telah mampu membuat wordpress khusus mengenai sejarah singkat Museum Tjok Agung Tresna serta telah membuat bebrapa akun media social seperti Instagram dan Youtube.

\section{UCAPAN TERIMAKASIH}

Penulis mengucapkan terima kasih kepada Rektor Universitas Udayana melalui Ketua LPPM UNUD dan Dosen Pembimbing Lapangan yang telah memfasilitasi pengabdian kepada masyarakat ini. Penulis juga mengucapkan terima kasih kepada Kepala Perbekel Desa Ayunan beserta jajarannya, Pendiri dan Pemilik Museum Tjok Agung Tresna, para kelian banjar di Desa Ayunan, dan rekan-rekan mahasiswa KKN PPM Universitas Udayana Desa Ayunan periode XIII Tahun 2016.

\section{DAFTAR PUSTAKA}

Crimm, L. Walter, 2009, Planning Successful Museum Bilding Project, Altamira press, America.

Peraturan Pemerintah Republik Indonesia No. 19, 1995, Pemeliharaan dan Pemanfaatan benda Cagar Budaya di Museum, Direktorat Jendral Kebudayaan, Departemen Pendidikan dan Kebudayaan, Jakarta

LPPM Unud 2016, Laporan Akhir Kegiatan KKN PPM Pediode XIII Desa Ayunan, Kecamatan Abian semal Kabupaten Badung. 